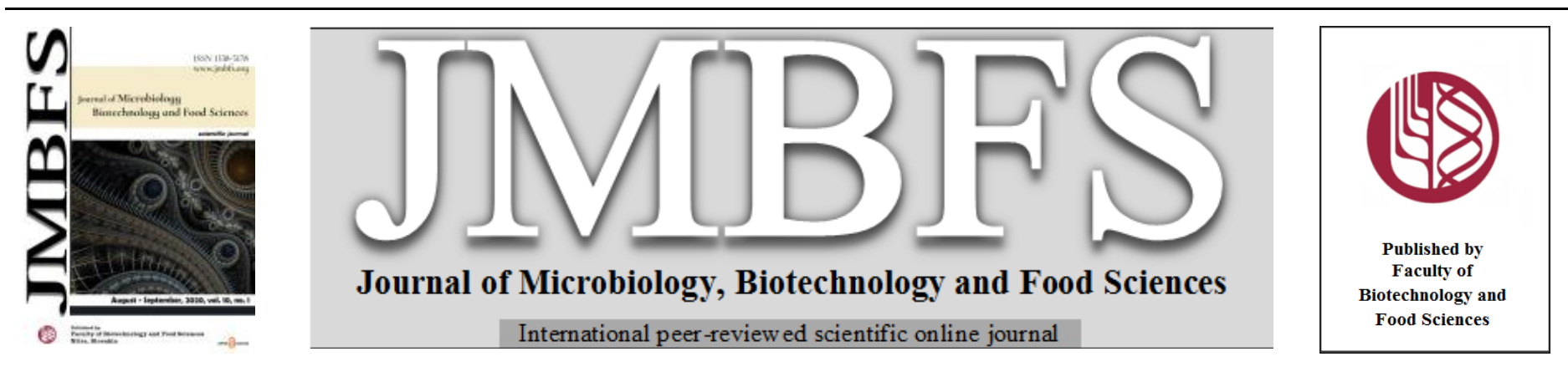

\title{
ATTRIBUTES OF PROSPECTIVE PLANT GROWTH PROMOTING HALOPHILIC BACTERIA (PGPHB) SCREENED FROM SALINE SOILS OF BARAMATI TEHSIL OF MAHARASHTRA STATE (INDIA)
}

\author{
Shrikumar V. Mahamuni* \\ $\operatorname{Address(es):~}$ \\ Department of Microbiology, Shardabai Pawar Mahila Arts, Commerce and Science College (Affiliated to Savitribai Phule Pune University, Pune), Malegaon Bk., \\ Baramati, 413115, Maharashtra State, India, Phone number: +91 2112254250.
}

*Corresponding author: drsvmahamuni@gmail.com

doi: 10.15414/jmbfs.2020.10.1.117-121

\section{ARTICLE INFO}

Received 2. 9.2018

Revised 7. 4. 2020

Accepted 21. 4. 2020

Published 1. 8. 2020

Regular article

open $O$ access

\section{ABSTRACT}

The important constraint for food production is soil salinity as it limits crop yield. In the present investigation, plant growth promoting halophilic bacteria (PGPHB) from saline soil of Baramati Tehsil of Maharashtra State were isolated, identified and characterized using physicochemical, biochemical, 16SrRNA gene sequencing and phylogenetic analysis. Plant growth promoting traits of two identified PGPHB were also detected. Isolates were moderate halophiles identified as Haererehalobacter sp. SM2 and Halomonas sp. SM3. They grew optimally within the range 3\% to10\% $\mathrm{NaCl}$ concentration. Both isolates were indol acetic acid producing, phoshate solubilizing and nitrogen fixing bacteria having big potential for bioremediation of salt affeced soils for crop production.

Keywords: PGPHB, Haererehalobacter, Halomonas

\section{INTRODUCTION}

Soil is the storehouse of plant nutrients but it cannot accomplish the demand by crop continuously season after season. Soil salinity is the burning problem among several abiotic stresses, deescalating crop produce (Mayak et al., 2004, Mittler, 2006). These problems are ubiquitous in the arid and semiarid areas and also in areas where ground waters of high salt content are the only source of water existing for irrigation (Giri et al., 2003). As reported by Land and Plant Nutrition Management Service of the Food and Agriculture Organization (FAO) of the United Nations salt affected soils have covered nearly $7 \%$ of the world's land area. In India salt affected soils are distributed over 7.044 million hectare area (Chopra and Paroda, 2015). The salt affected soils are categorized as saline or sodic (Szabolcs, 1989). One of the man derived reasons of soil salinity is hydrologic imbalance between applied water and water used by crops. The land clearing and the substitution of native vegetation with crops and irrigation using salt rich water or chemical fertilizers or having inadequate drainage-systems are the crucial causes behind the soil salinity complications. Usually sulphate, chloride and bicarbonate salts of $\mathrm{Na}^{+}, \mathrm{K}^{+}, \mathrm{Mg}^{2+}$, and $\mathrm{Ca}^{2+}$ contribute to the salinity of the soil (Munns and Tester, 2008).

Salinity directly or indirectly disturbs seed germination, respiration, photosynthesis, nitrogen fixation, phosphorus uptake and solubility of minerals, nodulation and also cell growth (Xu et al., 2000; Meloni et al., 2003; Parida and Das, 2005). Salts in soil increase ethylene level in root and are responsible for ionic imbalance as well as hyper-osmotic conditions in plant. Many technica measures have been developed to reclaim the saline soil including soil excavation and soil replacement, leaching, use of chemical and organic amendments. These technologies became less attractive to the farmers due to cost-effective practicability. Bacteria associated with plant growth generally increase plant immunity and productivity (Yildrim and Taylor, 2006). Yang et al. (2008) emphasized role of these bacteria in inducing systemic tolerance (IST) against salinity and drought conditions. Under salt stress condition many plant growth promoting bacteria (PGPB) revealed 1-aminocyclopropane-1-carboxylic acid (ACC) deaminase activity. The ACC deaminase diminishes the amount of ACC and ethylene level in root (Glick et $\boldsymbol{a l}$., 1998). Salinity also reduces microbia number along with diversity (Omar et al., 1994; Borneman et al., 1996). Thus to alleviate salt stress, an alternative is inoculation of plant growth promoting halophilic bacteria (PGPHB) on crop seeds and seedlings. Many researchers have reported salt tolerant PGPB such as Halobacterium, Ochrobactrum, Acinetobacterium, Bacillus, Enterobacter, Chromohalobacter, Halomonas, Oceanobacillus and others (Del Moral et al., 1988; Roohi et al., 2012; Anbumalar and Ashokumar, 2015; Tipre et al., 2015; Orhan, 2016; Sharma et al., 2016). In the present investigation PGPHB from salt affected area of Baramati Tehsil of Maharashtra State (India) were isolated, screened, identified and characterized using physicochemical, biochemical, plant growth promoting and 16SrRNA gene sequencing features.

\section{MATERIAL AND METHODS}

\section{Soil Sample collection}

Cautiously collected saline soil samples using sterile polythene bags from saline soils of Baramati Tehsil (Block) of Maharashtra state were immediately transported along with ice pack to the laboratory and kept in refrigerator before the isolation of PGPHB. Soil $\mathrm{pH}$ of each sample was determined before the enrichment study.

\section{Enrichment and isolation}

Soil samples were inoculated in the Abram and Gibbons (1960) medium including $10 \%$ sodium chloride $(\mathrm{NaCl})$ and incubated for 15 days at $30^{\circ} \mathrm{C}$ to enrich halophiles. The broth medium was prepared using distilled water which contained ( ${\mathrm{g} . \mathrm{dl}^{-1}}^{-1}$ ) yeast extract 1 ; sodium citrate 0.3 ; casmino-acid 0.5 ; peptone $0.5 ; \mathrm{MgSO}_{4} .7 \mathrm{H}_{2} \mathrm{O} 2 ; \mathrm{FeSO}_{4} .7 \mathrm{H}_{2} \mathrm{O} 0.005 ; \mathrm{KC} 10.2 ; \mathrm{NaCl} 10$. Using $1 \mathrm{~N} \mathrm{NaOH}$ and $1 \mathrm{~N} \mathrm{HCl}, \mathrm{pH}$ of medium was adjusted to $7.0( \pm 0.2)$. After enrichment sample was inoculated on same medium containing $2.5 \%$ agar for isolation of halophiles. Plates were incubated at $30^{\circ} \mathrm{C}$ for $24-48 \mathrm{~h}$. Different colonies were picked and pure cultures of pre-primary isolates of PGPHB were preserved.

\section{Screening of PGPHB}

The pre-primary isolates were spot-inoculated on Ashby's agar containing 5\% $\mathrm{NaCl}$ and incubated for $48 \mathrm{~h}$ at $30^{\circ} \mathrm{C}$. Ashby's agar contained (g.L $\left.\mathrm{L}^{-1}\right) \mathrm{K}_{2} \mathrm{SO}_{4} 0.1$; $\mathrm{K}_{2} \mathrm{HPO}_{4}$ 0.2; Mannitol 20; $\mathrm{NaCl} 50 ; \mathrm{MgSO}_{4} 0.2 ; \mathrm{CaCO}_{3} 5 ;$ Agar agar 25. The pH was adjusted at $7.4( \pm 0.2)$. Isolates showing growth were considered as nitrogen fixing primary isolates. Further phosphate solubilizing activity of nitrogen fixing halophiles was determined using Pikovskaya's agar medium (Pikovskaya, 1948). The $10 \mu \mathrm{l}$ suspension of each primary isolate having 0.3 optical densities was located on this agar and phosphate solubilization index (SI) was measured after incubation at $30^{\circ} \mathrm{C}( \pm 0.2)$ for 4 days for each isolate using the formula advocated by Edi-Premono et al. (1996) as-

$S I=(A+H) / A$ where, $A=$ Colony diameter, $H=$ Halo zone diameter 
Based on the nitrogen fixing ability and phosphate solubilization indices, two bacterial isolates were selected and preserved for further studies.

\section{Identification}

The isolates selected through screening were identified by microscopic, cultura and biochemical characterization as well as 16SrRNA gene sequencing and phylogenic analysis as per the methods adopted by Mahamuni (2011).

\section{i) Colony characters and microscopic analysis}

Isolates were cultivated on Abram and Gibbons agar containing $5 \% \mathrm{NaCl}$ and colony characters were noted. Isolates were also examined under compound microscope to determine cell morphology, Gram nature, motility, and presence of capsule and endospore.

\section{ii) Growth at different $\mathrm{pH}$, Temperature and Salt ( $\mathrm{NaCl}$ ) concentration}

Optimum temperature, $\mathrm{pH}$ and $\mathrm{NaCl}$ concentration were determined for each isolate using nutrient broth. Salt $(\mathrm{NaCl})$ concentration adjusted in nutrient broth used for temperature and $\mathrm{pH}$ determination was $5 \%$. The $\mathrm{pH}$ and salt range adjusted in different nutrient broth tubes were from 2 to 12 and $0 \%$ to $20 \%$, respectively. After inoculating the isolate-culture, nutrient broth tubes were incubated for $24 \mathrm{~h}$ at $30^{\circ} \mathrm{C}$ to find out optimum $\mathrm{pH}$ and salt concentration while other tubes incubated at $0^{\circ} \mathrm{C}, 4^{0} \mathrm{C}, 30^{\circ} \mathrm{C}, 37^{\circ} \mathrm{C}, 45^{\circ} \mathrm{C}$ and $55^{\circ} \mathrm{C}$ to find out optimum temperature. After incubation optimum growth in the form of turbidity was assessed using colorimeter adjusted at wavelength $(\lambda) 520 \mathrm{~nm}$.

\section{iii) Biochemical tests}

Biochemical tests were performed as described by Smibert and Krieg (1994) and Collins et al. (1995). Biochemical tests including enzyme activities such as catalase- using 3\% hydrogen peroxide $\left(\mathrm{H}_{2} \mathrm{O}_{2}\right)$ solution; oxidase- using $1 \%$ tetramethyl -p- phenylene diamine dihydrochloride solution; urease- using Christensen's urea agar; amylase- using starch agar and $1 \mathrm{~N}$ iodine solution; gelatinase- using gelatin agar and acidic mercuric chloride $\left(\mathrm{HgCl}_{2}\right)$ or Frazier's solution were determined qualitatively. The Sugar fermentation tests- using different sugars such as glucose, sucrose, lactose and mannitol as well as IMViC tests consisting Indol production- using peptone water, xylene and Kovac's reagent; Methyl Red- using glucose phosphate broth (GPB) and methyl red indicator; Voges-Proskauer test- using GPB and Barrit's reagent; and Citrate Utilization- using Koser's citrate broth were carried out by adopting standard methods. Hydrogen sulphide $\left(\mathrm{H}_{2} \mathrm{~S}\right)$ production- using lead acetate paper and nitrate reduction- abilities using peptone nitrate broth and nitrite detection reagen including sulphanilic acid and dimethyl alpha-naphthyl amine prepared in $5 \mathrm{~N}$ acetic acid were also tested for the isolates under study.

\section{iv) 16SrRNA gene sequencing}

The 16SrRNA gene sequences of both potential PGPHB-isolates were obtained to determine phylogenetic relationship by using standard methods and protocols
(Stackebrandet, 1991; Weisberg et al., 1989; Patel et al., 2001 and Tamura et al., 2004). Polymerase chain reaction (PCR) was employed for bacterial DNA isolation (MinElute PCR purification kit, Quiagen) and amplification of 16SrRNA gene using universal primers. The sequencing was carried out using Big Dye Terminator Ready Reaction kit on Genetic Analyser - ABI Prism 310 (Applied Biosystems, Foster City, CA) with $10 \mu 1$ reaction mix - Big dye terminator, $1.5 \mu \mathrm{l} ; 5 \mathrm{X}$ Sequencing dilution buffer, $1.0 \mu \mathrm{l}$; PCR amplified product $(10 \mathrm{ng} / \mu \mathrm{l}), 1.0 \mu \mathrm{l}$; Primer $(10 \mu \mathrm{M}), 1.0 \mu \mathrm{l}$, Sterile Milli Q water, $5.5 \mu \mathrm{l}$. The PCR conditions selected were 35 cycles; initial denaturation, $94^{\circ} \mathrm{C}$ for $2 \mathrm{~min}$; denaturation, $94^{\circ} \mathrm{C}$ for $60 \mathrm{~s}$; annealing, $55^{\circ} \mathrm{C}$ for $60 \mathrm{~s}$; and elongation, $72^{\circ} \mathrm{C}$ for $2 \mathrm{~min}$ with final $7 \mathrm{~min}$ extension at $72^{\circ} \mathrm{C}$ and a $4^{\circ} \mathrm{C}$ hold. The $16 \mathrm{SrRNA}$ gene sequences of the isolates were analyzed at NCBI GenBank (http://www.ncbi.nlm.nih.gov) using BLAST and Clustal W. Phylogenetic trees were constructed by neighbour joining method (MEGA 4 soft-ware). The final sequences of both isolates were submitted at GenBank to obtain accession numbers.

\section{Plant growth promoting traits}

In addition to biochemical tests as described above, plant growth promoting traits of both PGPHB were recorded. as per the methods described by the researchers Indol acetic acid (IAA) production ability was determined using Czapek Dox broth containing $1 \mathrm{mg} \mathrm{ml}{ }^{-1}$ L-tryptophan and orthophosphoric acid and Salkowski's reagent ( Bran, et al., 1991). Enzyme activities such as Chitinase (Shanmugaiah et al., 2008), protease (Laxmi et al., 2014), cellulase (Patagudi et al., 2014 ), acid and alkaline phosphatase (Tabatabai and Bremner, 1969; Eivazi and Tabatabai, 1977) were also determined. Siderophore production ability was confirmed by employing Chrom Azurol S agar (Schwyn and Neilands, 1987). Qualitative determination of zinc solubilization activity was carried out on Abram and Gibbons agar containing 5\% $\mathrm{NaCl}$ and $0.5 \%$ zinc oxide $(\mathrm{ZnO})$ as an insoluble zinc source. Isolated culture was spot inoculated on the medium and incubated at $30^{\circ} \mathrm{C}$ for 3-4 days. Appearance of clear zone surrounding the colony designated as positive zinc solubilizing activity.

\section{RESULTS AND DISCUSSION}

\section{Enrichment, Isolation and Screening of PGPH}

The $p H$ range found in collected soil samples varied from 8.8 to 9.4. Total 48 pre-primary cultures were isolated from enriched soil samples. This number was reduced to nine primary isolates by transferring pre-primary cultures on Ashby's nitrogen free mannitol agar. Among nine primary isolates final two PGPHB were selected considering phosphate solubilization indices (SI) on Pikovskaya's agar containing 5\% $\mathrm{NaCl}$. Phosphate solubilizing bacterial colonies produced zones of clearance around them due to the solubilization of insoluble tri-calcium phosphate from the Pikovskaya's agar. Particulars regarding screening of PGPHB are presented in a table 1.

Table 1 Screening of PGPHB

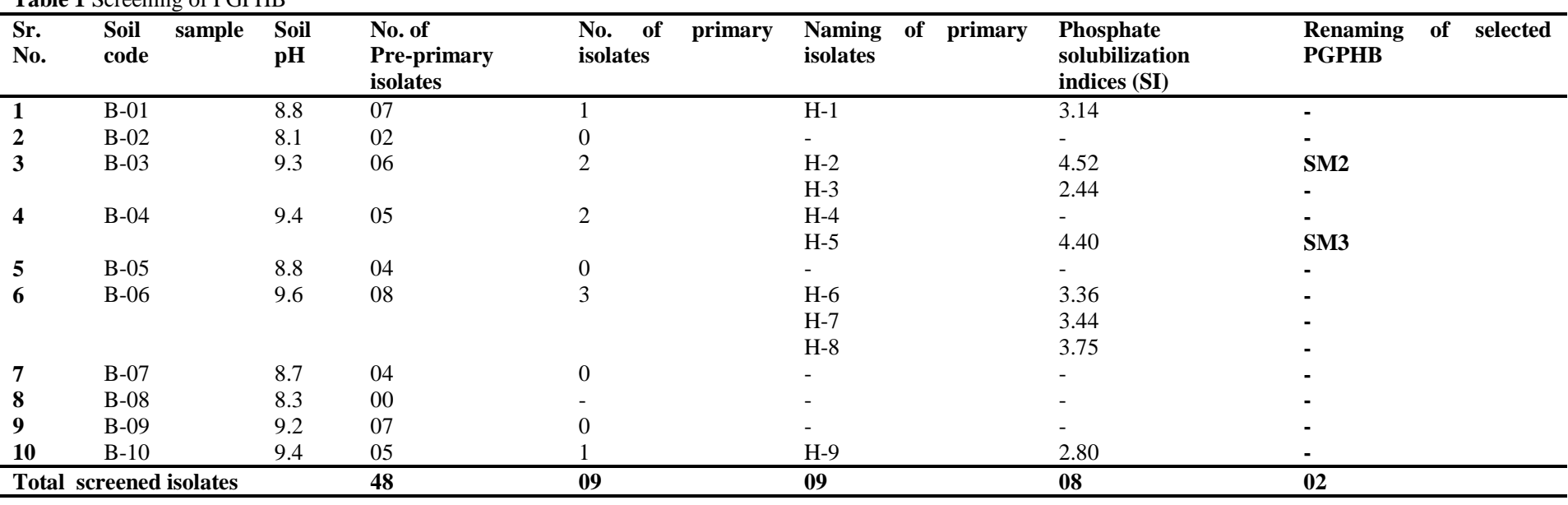

The plant growth promoting halophilic bacterial (PGPHB) eight isolates tolerated $10 \% \mathrm{NaCl}$ concentration and expressed nitrogen fixing and phosphate solubilizing abilities. Selected PGPHB namely isolate SM2 and isolate SM3 recorded phosphate solubilization indices (SI) as 4.52 and 4.40, respectively.

\section{Identification and plant growth promoting characterization}

Both the isolates developed circular, cream white, convex and opaque colony with moist consistency on Abram and Gibbons agar containing 5\% NaCl. Both SM2 and SM3 isolates were Gram negative, motile, rod shaped having dimensions $0.5-0.8 \mu \mathrm{m}$ by $1.6-2.0 \mu \mathrm{m}$. They were also recorded as non-spore forming as well as non-capsule forming bacteria. Both SM2 and SM3 isolates grew in nutrient broth containing $1 \%$ to $12 \% \mathrm{NaCl}$; but maximum growth was observed at salt concentration 3 to $10 \%$. They showed better growth at $30^{\circ} \mathrm{C}$ and $37^{\circ} \mathrm{C}$ than below $10^{\circ} \mathrm{C}$ and at and above $45^{\circ} \mathrm{C}$. They also showed optimum growth at range between $\mathrm{pH} 6$ and 10 and grew at $\mathrm{pH} 12$ also. Results regarding microscopic, cultural, biochemical and plant growth promoting characterization are presented in table 2 . 
Table 2 Microscopic, cultural, biochemical and plant growth promoting characterization

\begin{tabular}{|c|c|c|c|}
\hline Sr. No. & Characters & Strain SM2 & Strain SM3 \\
\hline 1 & Gram nature & - & - \\
\hline 2 & Motility & + & + \\
\hline 3 & Spore formation & - & - \\
\hline 4 & Capsule formation & - & - \\
\hline 5 & $\mathrm{PH}$ range & 6-10 & 6-10 \\
\hline 6 & Salt Conc. range & $1 \%-12 \%$ & $1 \%-12 \%$ \\
\hline 7 & Temperature range & $30-37^{0} \mathrm{C}$ & $30-37^{0} \mathrm{C}$ \\
\hline 8 & Catalase & + & + \\
\hline 9 & Oxidase & - & - \\
\hline 10 & Urease & + & + \\
\hline 11 & Amylase & - & - \\
\hline 12 & Gelatinase & - & - \\
\hline 13 & Nitrate reduction & + & + \\
\hline 14 & Indol & - & - \\
\hline 15 & Methyl Red & - & - \\
\hline 16 & Voges Proskauer & - & - \\
\hline 17 & Citrate & - & - \\
\hline 18 & $\mathrm{H}_{2} \mathrm{~S}$ & + & + \\
\hline 19 & Nitrogen fixation & + & + \\
\hline \multirow[t]{5}{*}{20} & Sugar Fermentation & & \\
\hline & i. Glucose & + & + \\
\hline & ii. Lactose & - & - \\
\hline & iii. Sucrose & + & + \\
\hline & iv. Mannitol & - & + \\
\hline 21 & Indol acetic acid & + & + \\
\hline 22 & Zinc solubilization & + & + \\
\hline 23 & Phosphate solubilization & + & + \\
\hline 24 & Chitinase & - & - \\
\hline 25 & Protease & + & + \\
\hline 26 & Cellulase & - & - \\
\hline 27 & Acid Phosphatase & + & + \\
\hline 28 & Alkaline Phosphatase & + & + \\
\hline 29 & Siderophore & + & + \\
\hline
\end{tabular}

On the basis of these biochemical characteristics, SM2 and SM3 isolates were identified and classified under the genus Halomonas as they showed nitrogen fixing ability and growth at temperature range $30^{\circ} \mathrm{C}$ to $45^{\circ} \mathrm{C}$, salt range $1 \%$ to $12 \%$, catalase and nitrate reduction positive and indol, methyl red and VogesProskauer tests as negative. Both isolates solubilized zinc oxide elucidating clear zones on agar media; produced indol acetic acid, siderophores and exhibited protease, acid and alkaline phosphatase and nitogen fixing abilities.

Both SM2 and SM3 PGPHB isolates were identified using 16SrRNA gene sequencing and phylogenetic analysis. These strains showed closest match with Haererehalobacter SO66 HQ631986 and Halomonas sp. C3 9, respectively according to the blast search analysis. NCBI GenBank assigned accession numbers to the deposited gene sequences of both isolates under study. They identified as Haererehalobacter sp. SM2 (Acc. no. KX376422.1) and Halomona sp. SM3 (Acc. no. MH333105.1), respectively. Figures 1 and 2 represent 16SrRNA gene sequences while figures 3 and 4 represent phylogenetic trees of two PGPHB isolates, respectively.

GGAGGGAGGGGGGGGGGGGGGTCGGAGAAACATGCAAGTCGAGCGG CAGCACGGGGAGCTTGCTCCCTGGTGGCGAGCGGCGGACGGGTGAGT AATGCATAGGAATCTGCCCGGTAGTGGGGGATAACGTGGGGAAACCC ACGCTAATACCGCATACGTCCTACGGGAGAAAGCGGAGGCTCTTCGG ACTTCGCGCTATCGGATGAGCCTATGTCGGATTAGCTGGTTGGTAAGG TAACGGCTTACCAAGGCGACGATCCGTAGCTGGTCTGAGAGGATGAT CAGCCACACTGGGACTGAGACACGGCCCAGACTCCTACGGGAGGCAG CAGTGGGGAATATTGGACAATGGGCGAAAGCCTGATCCAGCCATGCC GCGTGTGTGAAGAAGGCTTTCGGGTTGTAAAGCACTTTCAGCGAGGA AGAAAGCCTTTGGGTTAATACCCCAGAGGAAGGACATCACTCGcAGA AGAAGCACCGGCTAACTCCGTGCCAGCAGCCGCGGTAATACGGAGGG TGCGAGCGTTAATCGGAATTACTGGGGCGTAAAGCGCGCGTAGGTGG CtTGGCACGCCGGTTGTGAAAGCCCCgGGTCTCAACCTGGT

Figure 1 16SrRNA gene sequence of strain SM2

ATGCAGTCGAGCGGCAGCACGGGGAGCTTGCTCCCTGGTGGCGAGCG GCGGACGGGTGAGTAATGCATAGGAATCTGCCCGGTAGTGGGGGATA ACGTGGGGAAACCCACGCTAATACCGCATACGTCCTACGGGAGAAAG CGGAGGCTCTTCGGACTTCGCGCTATCGGATGAGCCTATGTCGGATTA GCTAGTTGGTAAGGTAACGGCTTACCAAGGCGACGATCCGTAGCTGG TCTGAGAGGATGATCAGCCACACTGGGACTGAGACACGGCCCAGACT CCTACGGGAGGCAGCAGTG

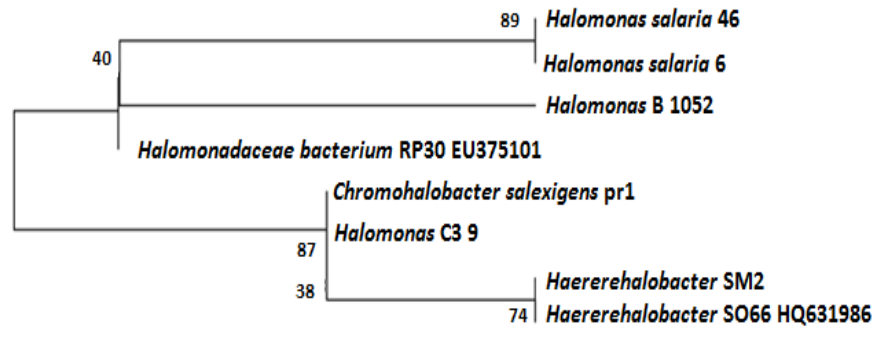

0.0005

Figure 3 Phylogenetic tree of strain SM2

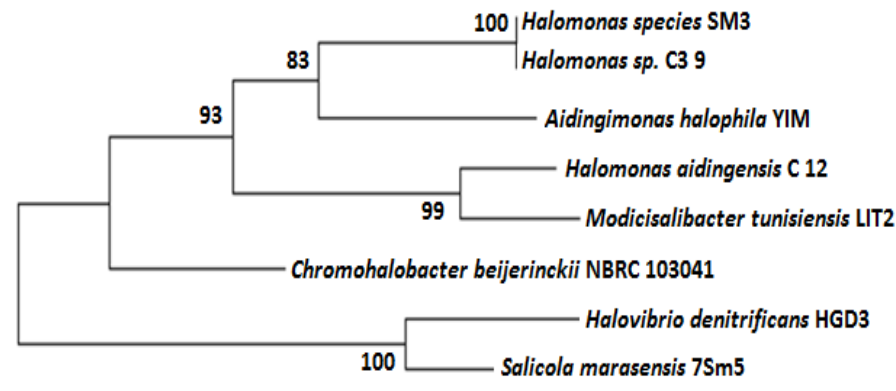

0.01

Figure 4 Phylogenetic tree of strain SM3

Both isolates grew best in the nutrient broth containing salt concentration range from 3 to $10 \%$ and hence they were confirmed as moderate halophiles (Kushner and Kamekura, 1988). In the present study isolates initially identified as Halomonas species as they grew well above $5 \% \mathrm{NaCl}$ concentration and revealed phosphate solubilization and nitrogen fixing positive. Isolates were catalase, urease, protease positive and not hydrolyzed gelatin and starch. They also reduced nitrate to nitrite. These results are in agreement with those of Mapelli $\boldsymbol{e}$ al. (2013). The present study made a first attempt to investigate local halophilic bacteria from saline soils of Baramati region. Halotolerant and halophilic bacteria were isolated by many researchers (Del Moral et al., 1988; Anbumalar and Ashokumar, 2015; Orhan and Gulluce, 2015; Sharma et al., 2016). The isolates reported were moderate halophiles rather than the extreme halophiles. Halophilic bacteria isolated grew best at temperature range $25-35^{\circ} \mathrm{C}$ and at $\mathrm{pH} 6$ 10 on media supplemented with $5 \% \mathrm{NaCl}$ concentration. The present study results are in close agreement with those reported by Rodrigues Valera (1988), Vahed et al. (2011), Roohi et al., (2012) and Azar et al. (2014). The halophilic bacterial cultures were identified by 16 SrRNA gene sequencing and phylogenetic analysis as identified by number of researchers (Kumar $\boldsymbol{e t}$ al., 2012; Fahimeh $\boldsymbol{e t}$ al., 2013; Gupta et al., 2015). Several halophilic bacterial isolates were documented as Gram negative by many researchers (Ventosa et al., 1998; Ghozlan et al., 2006; Phillips et al., 2012). Orhan et al. (2016) used plant growth promoting halotolerant bacteria having IAA production and phosphate solubilization abilities, to relieve salt-stress in wheat crop.

Microorganisms generally help plant to procure nutrients and enhance sustainability under biotic and abiotic stress situations through their diverse plant growth promoting(PGP) traits such as hydrolytic enzymes, IAA, Gibberelic acid (GA), siderophores, nitrogen fixing and phosphate-, zinc-, potash- solubilizing activities (Ruppel et al., 2013; Backer, et al., 2018; Fatima \& Arora, 2019). Most of the reported PGPB solubilize insoluble phosphates by either by producing organic acids, siderophores or phosphatases. Siderophores have high affinity for iron. By chelating iron they reduce availability of iron in environment and suppress the growth of phytopathogens. Catalase positive PGPB generally resist environmental, mechanical and chemical stress in plant rhizosphere. After solubilization of zinc and potash salts, they make these elements available for plants. They also produce plant growth auxin- IAA which induces cell division, root and shoot developments in plants. Many researchers have isolated plan growth promoting microbes and emphasized their PGP-biofertilizer-activities to enhance crop yield and soil fertility (Mahamuni, 2011; Tiwari et al., 2011; Geetha et al., 2014; Orhan, 2016; Marasco et al., 2016). Both Haererehalobacter species strain SM2 and Halomonas species SM3 strains exhibited similar plant growth promoting traits. These PGPHB can be employed as an alternative approach for salt-stress tolerance in many crops as clarified by Numan et al. (2018). 


\section{CONCLUSION}

The present investigation effectively isolated, screened and identified two bacterial strains from saline soils of Baramati Tehsil of Maharashtra and determined phylogenetic relationship with other bacterial species. Both isolates were identified as Haererehalobacter sp. SM2 (KX376422.1) and Halomonas sp. SM3 (MH333105.1). The study also revealed plant growth promoting traits of isolates viz., nitrogen fixation, phosphate and zinc solubilization, siderophore phosphatase and indol acetic acid production abilities. Inoculation of consortium of these two PGPHB isolates may be applied for reclamation of salt interfered soils and for increasing yield and nutrient uptake of crops. Therefore, further field studies must be needed for the development of biofertilizer using these potential isolates.

Acknowledgments: Author wishes to thank the mother Institute- Agricultura Development Trust and Krishi Vigyan Kendra, Baramati for the kind cooperation and support for the work on PGPHB

Conflict of Interest: The author confirms that no part of the manuscript has been plagiarized or self- plagiarized and declares no conflict of interest.

\section{REFERENCES}

Abram D. \& Gibbons, N. E. (1960). Turbidity of suspensions and morphology of red halophilic bacteria as influenced by sodium chloride concentration. Can. J. Microbiol., 6, 535-543.

Anbumalar, S. \& Ashokumar, P. (2015). Assessment of the effect of halo-tolerant bacterium on plant growth promotion. IJPCBS, 5(1), 287-293.

Azar, M., Uniyal, V., Chauhan, N. \& Rawat, D. S. (2014). Isolation and biochemical characterization of halophiles from Sahastradhara region, Dehradun, India. Int. J. Curr. Microbiol. App. Sci., 3(12), 753-760.

Backer, R., Rokem, J. S., Ilangumaran, G., Lamont, J., Praslickova, D., Ricci, E., Subramanian, S. \& Smith, D. L. (2018). Plant growth-promoting rhizobacteria: context, mechanisms of action, and roadmap to commercialization of biostimulants for sustainable agriculture. Front. Plant Sci. 9, 1473 https://doi.org/10.3389/fpls.2018.01473.

Borneman, J., Skroch, P. W., O’Sullivan, K. M., Palus, J.A., Rumjanek, N. G. \& Jansen, J. L. (1996). Molecular microbial diversity of an agricultural soil in Wisconsin. Appl. Environ. Microbiol., 62, 1935-1943.

Brick, J. M., Bostock, R. M. \& Silverstone, S. E. (1991). Rapid in-situ assay for indole acetic acid production by bacteria immobilized on nitrocellulose membrane. Appl. Environ. Microbiol., 57, 535-538.

Collins, C. H., Lyne, P.M. \& Grange, J. M. (1995). Microbiological methods. Butterworth and Heinnemann Publishers, London, UK. pp 155-168

Del Moral A., Prado, B., Quesada, E., Garcia, T., Ferrer, R. \& RamosCormenzana, A. (1988). Numerical taxonomy of moderately halophilic Gramnegative rods from an Inland Saltern. J. Gen. Microbiol., 134, 733-741.

Edi-Premono, Moawad, M. A. \& Vleek, P. L. G. (1996). Effect of phosphate solubilizing Pseudomonas putida on the growth of maize and its survival in the rhizosphere. Indonesian J. Crop. Sci., 11, 13-23.

Eivazi, F. \& Tabatabai, M. A. (1977). Phosphatases in soils. Soil Biol. Biochem. 9, 167-172. https://doi.org/10.1016/0038-0717(77)90070-0

Fahimeh, M., Nima, B. \& Majid, B. (2013). Isolation, characterization and identification of amylase producing halothermophilic isolates from Hows Soltan Lake, Iran. Afr. J. Microbiol. Res., 7(36), 4483-4490. https://doi.org/10.5897/AJMR12.1690

Fatima, T. \& Arora, N. K. (2019). Plant growth-promoting rhizospheric microbes for remediation of saline soils. In Arora, N. K. \& Kumar, N. (eds.), Phyto and Rhizo Remediation, Microorganisms for Sustainability. Springer Nature Singapore Pte Ltd., 9, 121-146. https://doi.org/10.1007/978-981-32-9664-0 5

Geetha, K., Venkatesham, E., Hindumathi, A. \& Bhadraiah, B. (2014). Isolation, screening and characterization of plant growth promoting bacteria and their effect on Vigna Radita (L.) R.Wilczek. Int. J. Curr. Microbiol. App. Sci., 3(6), 799-809. Ghozlan, H., Deif, H., Kandil, R. A. \& Sabry, S. (2006). Biodiversity of moderately halophilic bacteria in hypersaline habitats in Egypt. J. Gen. Appl. Microbiol., 52, 63-72.

Giri B., Kapoor, R. \& Mukerji, K. G. (2003). Influence of arbuscular mycorrhiza fungi and salinity on growth, biomass and mineral nutrition of Acacia auriculiformis, Biology and Fertility of Soils, 38, 170-175.

Glick, B. R., Penrose, D. M. \& Li, J. (1998). A model for the lowering of plan ethylene concentrations by plant growth-promoting bacteria. J. Theoretical Biol., 190 (1), 63-68.

Gupta, S., Sharma, P., Dev, K., Srivastava, M. \& Sourirajan, A. (2015). A diverse group of halophilic bacteria exist in Lunsu, a natural salt water body of Himacha Pradesh, India, Springer Plus., 4, 274, 1-9. https://doi.org/10.1186/s40064-0151028-1

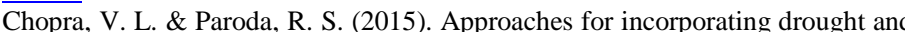
salinity resistance in crop plants. NIPA, New Delhi, 132p. ISBN 978-93-8330574-2
Kumar, S., Karan, R., Kapoor, S., Singh, S. P. \& Khare, S. K. (2012). Screening and isolation of halophilic bacteria producing industrial enzymes. Braz. J. Microbiol., 43(4), 1595-1603.

Kushner, D. J. \& Kamekura, M. (1988). Physiology of halophilic eubacteria. In Halophilic bacteria (ed. Rodriguez-Valera, F.), CRC Press, Boca Raton, FL USA. pp. 109-138.

Lakshmi, B. K. M., Ratnasri, P. V., Ambika Devi, K. \& Hemalatha, K. P. J. (2014). Screening, optimization of production and partial characterization of alkaline protease from haloalkaliphilic Bacillus sp. IJRET. 3(2), 435-443.

Mahamuni, S.V. (2011). Studies on phosphate solubilizing microorganisms from rhizosphere of sugarcane and sugar beet in relation to soil fertility and crop productivity, Ph.D. Thesis. Savitribai Phule Pune University (Formerly Known as University of Pune), Pune, India. http://hdl.handle.net/10603/139792

Mapelli, F., Marasco, R., Rolli, E., Barbato, M., Cherif, H., Guesmi, A., Ouzari, I., Daffonchio, D. \& Borin, S. (2013). Potential for plant growth promotion of rhizobacteria associated with Salicornia growing in Tunisian hypersaline soils BioMed Research International, 2013, 1-13. http://dx.doi.org/10.1155/2013/248078

Marasco, R., Mapelli, F., Rolli, E., Mosqueira, M. J., Fusi, M., Bariselli, P., Reddy, M., Cherif, A., Tsiamis, G., Borin, S., \& Daffonchio, D. (2016) Salicornia strobilacea (Synonym of Halocnemum strobilaceum) grown under different tidal regimes selects rhizosphere bacteria capable of promoting plant growth. Front. Microbiol., 7, 1286. https://doi.org/10.3389/fmicb.2016.01286

Mayak, S., Tirosh, T. \& Glick, B. (2004). Plant growth-promoting bacteria that confer resistance in tomato to salt stress. Plant Physiology and Biochemistry, 42, 565-572. https://doi.org/10.1016/j.plaphy.2004.05.009

Meloni D.A., Oliva, M.A., Martinez, C.A. \& Cambraia, J. (2003). Photosynthesis and activity of superoxide dismutase, peroxidase and glutathione reductase in cotton under salt stress. Environ. Exp. Bot., 49, 69-76.

Mittler, R. (2006). Abiotic stress, the field environment and stress combination. $\begin{array}{llll}\text { Trends in Plant } & \text { Science, } & 11(1), & 15-19\end{array}$ https://doi.org/10.1016/j.tplants.2005.11.002

Munns, R. \& Tester, M. (2008). Mechanisms of salinity tolerance. Annual Review of Plant Biology. 59, 651-681. http://dx.doi.org/10.1146/annurev.arplant.59.032607.092911

Numan, M., Bashir, S., Khan, Y., Mumtaz, R., Shinwari, Z. K., Khan, A. L., Khan, A. \& Al-Harrasi, A. (2018). Plant growth promoting bacteria as an alternative strategy for salt tolerance in plants: a review. Microbiological Research, 209, 21-32. https://doi.org/10.1016/j.micres.2018.02.003

Omar, S. A., Abdel-Sater, M. A., Khallil, A. M. \& Abd-All, M. H. (1994) Growth and enzyme activities of fungi and bacteria in soil salinized with sodium chloride. Folia Microbiol., 39(1), 22-28.

Orhan, F. (2016). Alleviation of salt stress by halotolerant and halophilic plant growth-promoting bacteria in wheat (Triticum aestivum). Braz. J. Microbiol., 47 621-627. https://doi.org/10.1016/i.bim.2016.04.001

Orhan, F. \& Gulluce, M. (2015). Isolation and characterization of salt-toleran bacterial strains in salt-affected soils of East Anatolian region, Geomicrobiology Journal, 32(1), 10-16, https://doi.org/10.1080/01490451.2014.917743

Parida, S. K. \& Das, A. B. (2005). Salt tolerance and salinity effects on plants Ecotoxicology and Environment Safety, 60, 324-349.

Patagundi, B. I., Shivasharan, C. T. \& Kaliwal, B. B. (2014). Isolation and Characterization of Cellulase producing bacteria from Soil. Int. J. Curr. Microbiol. App. Sci. 3(5), 59-69.

Patel, J. B. (2001). 16SrRNA gene sequencing for bacterial pathogen identification in the clinical laboratory. Mol. Diagn. 6, 313-321.

Phillips, K., Zaidan, F., Elizondo, O. R. \& Lowe, K. L. (2012). Phenotypic characterization and 16SrDNA identification of culturable non-obligate halophilic bacterial communities from a hypersaline lake, La Sal del Rey, in extreme South Texas (USA). Aquatic Biosystems, 8(5), 1-11. https://doi.org/10.1186/2046-9063-8-5

Pikovskaya, R.I. (1948). Mobilization of phosphorus in soil in connection with vital activity of some microbial species. Microbiologia, 17, 362-370.

Rodriguez-Valera F. (Ed.). (1988). Halophilic bacteria, Vol. II, CRC Press, Boca Raton

Roohi, A., Ahmed, I., Iqbal, M. \& Jamil, M. (2012). Preliminary isolation and characterization of halotolerant and halophilic bacteria from salt mines of Karak, Pakistan. Pak. J. Bot., 44, 365-370.

Ruppel S., Franken P. \& Witzel, K. (2013). Properties of the halophyte microbiome and their implications for plant salt tolerance. Functional Plant Biology, 40, 940-951. https://doi.org/10.1071/FP12355

Schwyn, B. \& Neilands, J. B. (1987). Universal chemical assay for the detection and determination of siderophores. Anal Biochem., 160, 47-56. http://dx.doi.org/10.1016/0003-2697(87)90612-9

Shanmugaiah, V., Mathivanan, N., Balasubramanian, N. \& Manoharan, P. T. (2008). Optimization of cultural conditions for production of chitinase by Bacillus laterosporous MML 2270 isolated from rice rhizosphere soil. Afr. J. Biotechnol., 7, 2562-2568.

Sharma, S., Kulkarni, J. \& Jha, B. (2016). Halotolerant rhizobacteria promote growth and enhance salinity tolerance in peanut. Front. Microbiol., 7, 1600 http://doi.org/10.3389/fmicb.2016.01600 
Smibert, R. M. \& Krieg, N. R. (1994). Phenotypic characterization. In Gerhardt, P., Murray, R. G., Wood, W. A., Krieg, N. R. (eds). Methods for general and molecular bacteriology ASM, 5, pp. 611-654.

Stackebrandet. (1991). Unifying phylogeny and phenotypic diversity. In the prokaryotes, vol. I, Edited by Balows, A., Truper, H. G., Dworkin, M., Harder, W. \& Schleifer, K. H., New York, Springer Verlag. pp. 1947.

Szabolcs, I. (1989). Salt-affected soils. CRC Press, Roca Raton, Florida.

Tabatabai, M. A. \& Bremner, J. M. (1969). Use of p-nirtophenyl phosphate for assay of soil phosphatase activity. Soil Biol. Biochem., 1, 301-307. https://doi.org/10.1016/0038-0717(69)90012-1

Tamura, K., Neo, M. \& Kumar, S. (2004). Prospects for inferring very large phylogenies using the Neighbour- Joining Method. Proc. Nat. Acad. Sci. USA 101, 11030-11035. https://doi.org/10.1073/pnas.0404206101

Tipre, S., Pindi, P. K. \& Sharma, S. (2015). Biotechnological potential of a Halobacterium of family Bacillaceae. Indian J. Biotechnol., 14, 65-71.

Tiwari, S., Singh, P., Tiwari, R., Meena, K. K., Yandigeri, M., Singh, D. P. \& Arora, D. K. (2011). Salt-tolerant rhizobacteria-mediated induced tolerance in wheat (Triticum aestivum) and chemical diversity in rhizosphere enhance plant growth. Biol. Fertil. Soils, 47, 907-916. https://doi.org/10.1007/s00374-0110598-5.

Vahed, S. Z., Forouhandeh, H., Hassanzadeh, S., Klenk, H. P., Hejazi, M. A. \& Hejazi, M. S. (2011). Isolation and characterization of halophilic bacteria from Urmia Lake in Iran. Microbiology, 80(6), 834-841.

Ventosa, A., Nieto, J.J. \& Oren, A. (1998). Biology of moderately halophilic aerobic bacteria, Microbiol. Mol. Biol., 62, 504-544.

Weisberg, W. G., Tully, J. G., Rose, D. L., Petzel, J. P., Oyaiz, U. H., Yang, D. Mandelco, L., Sechres, J. T., Lawrence E. G., Vanette, N. J., Manilof, F. J. \&

Woese, C. R. (1989). A phylogenetic analysis of the mycoplasmas: Basis for their classification. Journal of Bacteriology, 171, 6455-6467.

Xu, G., Magen, H., Tarchitzky, J. \& Kafkaki, U. (2000). Advances in chloride nutrition. Advances in Agronomy, 68, 96-150.

Yang, J., Kloepper, J. W. \& Ryu, C. M. (2008). Rhizosphere bacteria help plants tolerate abiotic stress. Trends in Plant sci. 14(1), 1-4.

Yildirim, E., Taylor, A. G. and Spittler, T. D. (2006). Ameliorative effects of biological treatments on growth of squash plants under salt stress. Scientia Horticulturae.111, 1-6. 